\title{
Comparative Advertising and Competition Policy
}

\author{
Francesca Barigozzi ${ }^{*}$ \\ University of Bologna \\ Martin Peitz ${ }^{* *}$ \\ International University in Germany
}

\begin{abstract}
:
Only recently, competition authorities tend to agree on comparative advertising being helpful in promoting competition. They now encourage firms to use it. They reason that comparative advertising, if fair and not misleading, increases consumers' information about alternative brands. For this to work, comparative claims must be credible. Competition policy and legal practice are essential in making comparative advertising (directly and indirectly) informative.

In this paper, first we provide a legal background of comparative advertising in in Europe and the US. Second, we provide an economic analysis of comparative advertising. Here, we discuss the ways comparative advertising can affect market outcomes. Third, we provide an analysis of some recent legal cases in Europe and the US. Overall, we focus on the scope of information transmission through comparative advertising and on the way antitrust laws affect it.
\end{abstract}

\footnotetext{
* Address: University of Bologna, Department of Economics, Strada Maggiore 45, 40137, Bologna, Italy, Email: barigozz@spbo.unibo.it.

** Address: School of Business Administration, International University in Germany, 76646 Bruchsal, Germany, Email: Martin.Peitz@i-u.de.
} 


\section{Introduction}

Until very recently several continental European countries completely had banned any form of comparative advertising whereas, in the US, the use of comparative advertising has actually been encouraged by the Federal Trade Commission since the 1970's. While in the past the European and American approach towards this type of advertising was markedly different, today competition authorities agree in considering comparative advertising an important tool in promoting competition, such that firms and retailers are stimulated to use comparative ads. The reason is that comparative advertising, if fair and not misleading, is claimed to increase consumers' information about alternative brands, products and services and to positively affect competition among (domestic and cross-border) firms. In particular, the argument goes that direct comparison ads would encourage consumers to make more informed purchasing decisions - moreover, comparison ads would ease the consumer's task of evaluating the performance of particular brands against other brands.

A particular understanding of this idea is the following (we elaborate on this in section 3 ). With respect to generic advertising, comparative claims provide information which is easily converted in operational knowledge by consumers. Often, content-based advertising which does not make comparisons is of little meaning to consumers. When this is the case, the consumers' ability in processing comparative ads should be higher because comparative claims refer to experimented aspects of past consumption or serve as a reference point.

For information transmission to work, consumers must not be deceived. Here, laws and legal practice are essential to facilitate that comparative advertising claims are truthful. In particular, competition policy must be designed such that the consumers' and the competitors' interest in truthful information transmission can be assured.

This paper analyzes the regulation of comparative advertising by competition policy and, in particular, focuses on how such regulation affects the signaling role and the role for competition of comparative ads. We address a set of questions: What is the legal history of comparative advertising? What is the current legislation with respect to comparative advertising in the US and Europe? How does comparative advertising affect market outcomes? In particular, what is the scope of information transmission of comparative advertising and how is it affected by competition policy? And finally, what should be kept in mind when designing competition policy?

Before answering these questions, we provide definitions of comparative advertising and document its importance as a marketing practice. 


\section{Definition of comparative advertising}

According to the Federal Trade Commission (FTC) in the US, "Comparative advertising is defined as advertising that compares alternative brands on objectively measurable attributes or price, and identifies the alternative brand by name, illustration or other distinctive information" (Statement of Policy Regarding Comparative Advertising, Federal Trade Commission, Washington, D.C., August 13, 1979).

In the European Union, enactment of directive 97/55/EC concerning misleading and comparative advertising reads: "comparative advertising means any advertising which explicitly or by implication identifies a competitor or goods or services offered by a competitor". ${ }^{1}$

Comparative advertising can be classified according to whether it is direct or indirect. In direct comparative ads the competing products either are explicitly named or can be precisely identified (by photos, images or trademarks). We give two examples. In 1991 MasterCard launched a "campaign that used funny 30-second commercials to depict frenzied American Express Card holders rushing madly around unsuccessfully trying to find an ATM that would take their card" (Leighton 2004). A 1999 General Motors Corp. ad claimed that the Cadillac Seville STS outperforms BMW 540 in a slalom race. By contrast, indirect comparative ads do not directly refer to competing brand names. The Avis "We try harder" campaign launched in the US in 1962 is perhaps the most famous example. ${ }^{2}$

\section{Diffusion of comparative advertising}

Comparative advertising is considered a quite aggressive marketing practice. Sectors most affected by rules on comparative advertising include food, retail, motoring and airlines. Famous examples of direct comparative ads involve Coke and Pepsi, Burger King and McDonald's, Unilever and Procter and Gamble (see David Teather in Marketing; London; May 11, 2000).

Different studies suggest varying figures on the relative use of comparative advertising in the US. Muehling et al. (1990) find that around 40 percent of all advertising is comparative. Pechmann and Steward (1990) find on a different data set that 60 percent of all ads are indirectly comparative, 20 percent contain direct comparative claims; the rest are non-comparative. In general, comparative advertising is seen as an important option within the different possibilities of advertising.

\footnotetext{
${ }^{1}$ In the real world we can observe advertising campaigns where the sponsoring brand simply declare the merits of its product with respect to the competitors' one, and others ads explicitly degrading the competing brands.

2 "In 1962 Hertz was the clear leader in the car rental business, with Avis as one of the brands in the following pack. The Avis 'We try harder' campaign repositioned Hertz creating a relative, believable and compelling strength for Avis. The market dominance of Hertz became a weakness and Avis became the 'right choice' in the mind of consumers." From BuildingBrands on the website http://www.buildingbrands.com. The campaign can be seen as the first "modern" use of comparative ad in advertising history (see Bixby and Lincoln, 1989, and references therein).
} 
In most European Union countries comparative advertising is a quite young phenomenon, as we will see in the next section. We are not aware of any systematic study about its diffusion. Probably the lack of harmonization of comparative advertising rules among the European Countries, despite the Directive 97/55/EC, and the subsequent legal risks faced by the advertising firms still represents an obstacle for its diffusion. ${ }^{3}$ Also, since consumers have been less exposed to comparative advertising, advertisers may be more critical of its effectiveness in Europe.

The lack of harmonization within Europe and across different countries more generally is even more relevant today because of the increasing commerce on the internet. With on-line product searching and distance selling comparative advertising has received renewed attention. The explosive growth of Internet advertising forces practitioners to verify whether their ads comply with international comparative advertising standards and social norms. In the words of Freeman and Nemiroff (2001), "... if you decide to use comparative advertisements as a marketing tool in a foreign country, or even if your online ad results in sales to foreign consumers, it is important to first obtain a complete legal assessment of that country's advertising laws."4

\section{Comparative ads from the marketing literature perspective}

Apart from legal risks, a number of advertisers have been reluctant to use comparative because some long-term consequences of comparison advertising may be seriously detrimental to the advertising firm. A first potentially negative effect of comparison advertising is the misidentification of sponsoring brands: comparison ads might increase the salience of competing brand without improving consumer awareness of the brand sponsoring the message. A second important possible negative impact of comparison advertising concerns credibility: an ad for one brand might not be viewed by consumers as a highly credible source of information about competing brands because of a logical likelihood of manipulative intent (see Wilkie and Farris, 1975).

In the marketing literature on comparison ads the general effectiveness of comparative advertising is still controversial (see Prasad 1976, Pechmann and Ratneshwar 1991, Jain et al. 1998, Barone and Miniard 1999). Nevertheless, a general agreement exists concerning the fact that a low-share or unfamiliar brand (the underdog) can enhance the relevance of an ad by naming a leading brand that consumers regularly purchase. In other words comparison ads should be more effective in stimulating initial attention towards small firms wishing to take on established brands (e.g. Muehling et al. 1990, Pechmann and Stewart 1990). For example, citing the words of the dealer marketing manager at Mitsubishi, the company used comparative advertising when entering the

\footnotetext{
${ }^{3}$ Such a harmonization is defended on the ground that the differences in the treatment of comparative advertising among member states is an impediment to the free flow of goods and communications within the EU (see Petty and Spink, 1995).

${ }^{4} \mathrm{~A}$ legal issue related to Internet comparative advertising is that of jurisdiction. Since the Internet is accessible from most countries, a comparative ad that is legal in the country where the ad originates may be viewed by consumers in a country that restricts such advertising practice (see also Berns Wright and Morgan, 2002).
} 
European market, "to guide the consumer by making associations with top brand names" (Director; London; June, 2000; Alison Coleman). This is the so called "underdog hypothesis", for an exposition from the marketing perspective we refer to Gnepa (1993).

\section{Plan of the paper}

In section 2 we explore the legal background. We provide answers to the first two questions posed above, namely we elaborate on the legal history of comparative advertising and the current legislation with respect to comparative ads in the US and Europe. In section 3 we explore some economic perspectives on comparative advertising. We provide answers to the third and fourth question, namely we analyze how comparative advertising may affect market outcomes. In particular, we elaborate on the scope of information transmission of comparative advertising and on how it is influenced by competition policy. In section 4 we present a number of legal cases. They suggest additional considerations with respect to the above questions. They also provides a partial answer on the fifth question, namely on what should be kept in mind when designing competition policy with respect to comparative advertising. Section 5 concludes.

\section{Legal Background}

\section{Comparative advertising in the US}

In the US, federal advertising legislation is found in two major laws: the Federal Trade Commission Act and the Trademark (Lanham) Act (the federal trademark statute prohibiting false designations of origin and false or misleading descriptions of facts). The Federal Trade Commission, when it was founded in 1914, had as its mission to protect businesses against unfair practices. In 1922 the Supreme Court ruled that the FTC has the right to regulate advertising. Specifically, this ruling allowed the FTC to regulate all aspects of false labelling and unfair methods of competition in advertising. Comparative advertising became an important issue in the 1960's and 1970's. Early on the FTC has emphasized that comparative advertising is a means to transmit information to consumers. In 1963 the FTC narrowed an order with respect to comparative advertising so as to allow firms to make "truthful and non-deceptive statements that a product has certain desirable properties or qualities which a competing product or products do not possess. Such a comparison may have the effect of disparaging the competing product, but we know of no rule of law which prevents a seller from honestly informing the public of the advantages of its products as opposed to those of competing products." (60 F.T.C. at 796)

The relatively sudden increase, during the 1970s and 1980's, in the use of explicit comparisons in advertising in the US, was in part a result of a Federal Trade Commission appraisal of such a practice as a means of improving competition. The FTC statement reads: "The Commission has supported the use of brand comparisons where the bases of comparison are clearly identified. Comparative advertising, when truthful and non-deceptive, is a source of important information to consumers and 
assists them in making rational purchase decisions. Comparative advertising encourages product improvement and innovation, and can lead to lower prices in the marketplace." (Statement of Policy Regarding Comparative Advertising, Federal Trade Commission, Washington, D.C., August 13, 1979)

Both competitors and consumers can address to the FTC for controversies arising from comparative advertising. Nevertheless most complaints about comparative advertising actions have not come from consumers, but instead from the firms which were the target of the comparison. Since 1974, plaintiffs, instead of addressing to the FTC, started ordinary Court actions applying to the 1946 Lanham Act. ${ }^{5}$ These firms have found that section 43(a) of the Lanham Act (although it does not mention advertising) holds in the words of Bixby and Lincoln (1989, page 145) "the key to getting more expedient and decisive action taken on their complaints. [...] Section 43(a) of Lanham Act was largely intended to clarify trademark, "palming off", and other trade law issues. However, it has been used as a basis for private litigation against companies promulgating allegedly false comparative advertising."

The amended Section 43(a) of the Lanham Act says that "any person who, on or in connection with any goods or services ... uses in commerce any word, term, name, symbol, or device, or any combination thereof, or any false designation of origin, false or misleading description of fact, or false or misleading representation of fact, which ... in commercial advertising or promotion, misrepresents the nature, characteristics, qualities, or geographic origin of his or her or another person's goods, services, or commercial activities, shall be liable in a civil action by any person who believes that he or she is or is likely to be damaged by such act." Plaintiffs typically have used section 43(a) of the Lanham Act rather than the FTC Act "because (1) it may give them immediate relief from competitive advertising by means of an injunction, (2) it may oblige the competitor to run corrective advertising, and (3) it may allow the plaintiff to collect damages from the defendant." (Bixby and Lincoln, 1989, page 145).

\section{Legal practice: standards of substantiation}

An important issue is whether the standards of substantiation are to be higher using comparative advertising compared to other forms of advertising which makes claims about product characteristics. The position of the FTC, as stated in 1979, reads: "On occasion, a higher standard of substantiation by advertisers using comparative advertising has been required by self-regulation entities. The Commission evaluates comparative advertising in the same manner as it evaluates all other advertising techniques. The ultimate question is whether or not the advertising has a tendency or capacity to be false or deceptive. This is a factual issue to be determined on a case-bycase basis. However, industry codes and interpretations that impose a higher standard of substantiation for comparative claims than for unilateral claims are inappropriate and

\footnotetext{
${ }^{5}$ Leigton (2004, p. 585), reads: "It took Congress over 30 years to catch up with the courts. The Trademark Law Revision Act of 1988 amended Section 43(a) of the Lanham Act to ratify the robust false advertising cause of action that has been developed judicially".
} 
should be revised." (Statement of Policy Regarding Comparative Advertising, Federal Trade Commission, Washington, D.C., August 13, 1979)

We like to make two important caveats here. (i) Since competitors can take actions against comparative claims and much less so against claims that are not comparative, the FTC statement of non-discrimination may not correspond to legal practice. (ii) The FTC statement becomes empty, if comparative advertising is the only means to communicate content about a product to consumers. This is the case if a competitor's product serves as a reference point for consumers because consumers do not have an understanding for absolute content statements.

"To state a cause of action for misleading advertisement under the Lanham Act, $a$ plaintiff must establish the following: 1) the defendant has made false or misleading statements of fact concerning his own product or another's; 2) the statement actually or tends to deceive a substantial portion of the intended audience; 3) the statement is material in that it will likely influence the deceived consumer's purchasing decisions; 4) the advertisements were introduced into interstate commerce; and 5) there is some causal link between the challenged statements and harm to the plaintiff." (Leighton 2004, page 588).

"When materiality has to be proven under the Lanham Act, it usually must be shown that the claim at issue likely would affect purchase decisions of a significant percentage of the intended audience." (Leighton, 2004). The plaintiff must provide clear results from consumers' surveys about how consumers interpret the claim and subsequently exert purchasing choices. Notice that even if the claim is not literally false it is actionable if it provides consumers with a wrong perception of reality. In other words the content of an ad is important (it must be true) but also the general impression given to consumers matters. In particular, what matters is the way consumers interpret the ad. To summarize, two situations are possible. An ad may have a literally false statement but not be deceptive or misleading in its net impression. Or every claim in an ad may be literally true, but the net impression given by the ad can be misleading. As Wood (2003) reports: "most cases involve advertising that contains literally true statements when viewed out of context but, as presented, leaves a false or deceptive net impression."

More specifically, courts place false or misleading advertising into three categories: implied falsity, literal falsity and mere puffery. Only the first two categories are actionable. "Most plaintiffs prefer the court to categorize the challenged advertising as literally false because the element of deception is presumed and no costly consumer survey is required" (McKenna and Manning 2002, p. 2). ${ }^{6}$

The third category is not actionable. Puffery can be used as a defense in Lanham Act false advertising cases. When such a defense succeeds, the court finding is that the claim in the ad is merely the seller's opinion and therefore non-actionable puffery. The courts and regulatory agencies find an advertising claim to be mere puffery when it

\footnotetext{
${ }^{6}$ See also Pizza Hut v. Papa John's, as discussed in section 4.
} 
obviously is not material to reasonable potential customers. In other words the claim clearly reports the seller's opinion and "no sensible man takes seriously". We can distinguish between "puffery by exaggeration, bluster, boast or humor" (the MasterCard advertising mentioned in the introduction falls in such a category). And "puffery by vagueness and/or seller's opinion" as the ad "the most beautiful car on the market" (see Leighton 2004). However, the world of puffery is quite small for comparative ads, as Pizza Hut v. Papa John's exemplifies (although the federal court's decision was overturned). This case is discussed in section 4.

Also, comparative ads which may be defended as puffery may be ruled to violate trademark anti-dilution law. Section 43(c) of the Lanham Act contains the important norm concerning Trademark Dilution, i.e., disparagement, blurring or alteration of a competitor's "famous" trademark. It aims at preventing the reduction of a trademark's selling power. If a firm is the target of a comparison ad, it can base its lawsuit on Section 43(c) whenever the advertising campaign alters or distorts its trademark in any way that could be regarded as spoofing the mark. More than twenty States in the US have anti-dilution laws which sometimes are stricter than the corresponding federal law (as the New York's trademark anti-dilution statute). Recently, in the case Deere \& Company v. MTD Products, Inc., the court dismissed the allegation based on the Section 42(a) of the Lanham Act and found that the comparative statements were true. Anyway, the Court of Appeals for the Second Circuit of New York affirmed a lower court's injunction barring the comparative advertising because it violated New York's trademark anti-dilution statute. ${ }^{7}$ One law firm argues that other States would now look to New York' Court of Appeals as persuasive authority and follow its interpretation of what constitutes "dilution" (see Wood, 2004).

\section{Legal practice: damages}

Section 35 of the Lanham Act allows plaintiffs to claim a number of damages: lost profits, corrective advertising expenses to help regain loss business, attorneys' fees, and punitive damages. Standards of proof for recovering damages for false advertising are high. In fact, to be entitled to damages, a plaintiff must show that consumers were actually deceived by the defendant's false advertising and that there was a direct cause or connection between the alleged false advertising and the injury of the plaintiff. "However, in several cases, the courts have dispensed with the requirement that actual deception be proven where the defendant's conduct was found to be wilful" (Raymond, 2004). Thus, when misrepresentations in the ad are wilful and egregious, actual deception is presumed and even punitive damages can be awarded. Anyway, damage awards have not been common in Lanham Act cases. On the contrary, only a dozen of court decisions provided for damages awards in false advertising cases and only some of them refer to comparative ad. The most important case, with a 40 Mio $\$$ reward, is U-

\footnotetext{
7 The comparative advertising commercial for Yardman, MTD's lawn tractor used an altered animation of Deere's well-known trademark logo: a "leaping deer". In the comparative television commercials, a smaller, blurred version of this deer was depicted running across the screen in fear of an MTD tractor. However, if MTD had used the image correctly, Deere Co. would have had no basis for a lawsuit.
} 
Haul International Inc. v. Jartran, Inc., 793 F.2d 1034 (9 ${ }^{\text {th }}$ Cir. 1986). We will shortly discuss this case in section 4.

The law firm Arnold and Porter suggests that damages are so rare because of the perceived difficulty of proof. ${ }^{8}$ Other authors argue that the courts are sceptical towards comparative claims in litigations concerning trade mark infringement or malicious falsehood. In particular Swan (2000, page 4) reads: "judges take the view that the public is neither gullible nor particularly trustful of advertising. Even if a cause of action is established, judges take some convincing that a comparative advertisement has caused any damage".

\section{Comparative advertising in the $E U$}

Until very recently, comparative advertising was essentially not allowed in European countries. The explicit identification of competitors had been banned in Belgium, Italy and Luxemburg. It was generally prohibited as unfair competition in Germany and France, unless advance notification was given to the competitor. Limited comparative advertising was permitted in Spain and the Netherlands. ${ }^{9}$ The use was restricted by the criteria of strict truthfulness and relevance in Scandinavia (see e.g. J. Dickerson and P. Jordan from the DLA Group in the UK, www.dla.com). In particular "the explicit identification of a rival or its product constituted unauthorized use of the rival's trademark or unfair denigration" (Petty and Spink, 1995). Recently, the UK had, compared with other Member States, a reputation of taking a rather relaxed approach (see below).

The European Union first addressed the issue of comparative advertising in the late 1970s. The position was that comparative advertising should be legal if it provides verifiable details and is neither misleading nor unfair. However, laws on comparative advertising were harmonized only in April 2000 (almost 20 years after its first proposal). "The preamble of the directive indicates that for goods to flow freely throughout the EC, the rules governing the form and content of advertising must be uniform and notes that this currently is not the case with comparative advertising. The preamble emphasizes comparative advertising's importance as a consumer decisionmaking tool and a stimulus of competition." (Petty and Spink, 1995)

According to current European legislation comparative advertising is allowed only if it is not misleading, compares like with like, does not create confusion, discredit or take unfair advantage of a rival's trademark or present goods as imitations of those bearing a

\footnotetext{
${ }^{8}$ They also suggest that this may be due to out-of-court settlements after the grant or denial of a preliminary injunction. See the newsletter Consumer Product Marketing, 2002(2) by Arnold and Porter.

${ }^{9}$ For example, the Netherlands Supreme Court condemned a comparative advertisement that promoted one brand fertilizer claiming that lower amounts are needed than with a competing brand. The Court admitted the general possibility of individual brand comparisons. However, it condemned the particular advertisement on the ground that it did not disclose the difference in composition between the two products (see Petty and Spink, 1995, and references).
} 
protected trade name. To be more precise, it is state in article $3 \mathrm{a}$ of the Directive 97/55/EC of European Parliament and of the Council of 6 October 1997 that

Comparative advertising shall, as far as the comparison is concerned, be permitted when the following conditions are met: (a) it is not misleading ...; (b) it compares goods or services meeting the same needs or intended for the same purpose;

(c) it objectively compares one or more material, relevant, verifiable and representative features of those goods and services, which may include price; (d) it does not create confusion in the market place between the advertiser and a competitor or between the advertiser's trade marks, trade names, other distinguishing marks, goods or services and those of a competitor; (e) it does not discredit or denigrate the trade marks, trade names, other distinguishing marks, goods, services, activities, or circumstances of a competitor;

(f) for products with designation of origin, it relates in each case to products with the same designation;

(g) it does not take unfair advantage of the reputation of a trade mark, trade name or other distinguishing marks of a competitor or of the designation of origin of competing products ${ }^{10}$; (h) it does not present goods or services as imitations or replicas of goods or services bearing a protected trade mark or trade name.

Several of the restrictions on comparative advertising can be defended by commonsense, although they are open for interpretation, as we illustrate in Section 4. However, a defense of condition (f) is less clear as it requires comparisons to products with the same designation. In particular, this effectively reduces the possibility of imports to establish themselves against certain home-grown products.

The authority responding to controversies arising from comparative advertising is the competition authority in every member state. However, the directive provides for the possibility of ordinary Court actions when comparative advertising consists in acts amounting to unfair competition, or infringes the laws on copyright, trademarks or other distinguishing signs. In particular, not only the competitor but also consumers and their organizations and associations can directly apply to a court.

In Section 7 (administrative and judicial remedies) of the Directive 97/55/EC it is written that (i) the ad deemed to be unlawful can be provisionally suspended by the Authority; (ii) the advertiser can be asked to furnish evidence as to the accuracy of factual claims in the ad, if evidence is not given or is deemed inadequate, the factual data shall be considered false; (iii) when the Court rules in favor of the plaintiff, the misleading ad must be stopped and eventually the Court's judgment published, moreover, the advertiser can be asked to publish a corrective ad.

\footnotetext{
${ }^{10}$ Notice that point $(\mathrm{g})$ is particularly relevant for the "underdog case".
} 
As Petty and Spink (1995, page 317) observe, "the tenor and language of the European (proposal) directive contrast sharply with the permissiveness of U.S. policy toward comparative advertising. Although legal violations, such as trademark infringement, disparagement, and passing off, are recognized in both the United States and Europe, they are more broadly construed in Europe." Moreover, they claim that "in many cases, comparisons allowed in the United States will be prohibited in Europe."

As we mentioned before, within the EU the UK has today a rather relaxed attitude towards comparative advertising. Nevertheless, to compare the legal approaches to comparative advertising characterizing European countries and the US it is useful to consider the UK as an example for an EU country. In both countries the interpretation by the courts is of particular importance because both, the UK and the US, have a common law legal system, where court cases provide precedent, i.e. these cases are used by other courts within the same jurisdiction when making decisions in comparable cases.

\section{Particular country study: UK}

Before 1994 comparative advertising were prohibited in the UK because it amounted to trade mark infringement. Then, section 10(6) of the Trade Mark Act (TMA) permitted the use of another trademark for purpose of making a comparison within certain guidelines. As Berns Wright and Morgan (2002, page 14) put it: "the TMA provides that trademarks must not be used other than in accordance with honest practice. The courts' test for honesty is an objective one. They ask: would a reasonable reader, accustomed to advertisings' use of hyperbole and even "knocking copy"11, find the advertisement so biased or misleading to be dishonest? The comparison must be between products intended to meet the same needs or intended for the same purpose. The comparison must be material, relevant, representative, and verifiable." Moreover, comparative advertising must not create confusion, nor creating the impression of a link between different trademarks. In the cases of alleged trademark infringement, the plaintiff, who is the trademark owner, has to prove that the use of the trademark is not honest. $^{12}$

Some years later the TMA approval, the European Directive on comparative advertising was implemented in the UK with the Control of Misleading Advertising (Amendment) Regulations 2000. As Dickerson and Jordan (2003) observe, the harmonization initiative did not mean for the UK a relaxation of the law on comparative advertising, contrary to what happened in the other Member States.

Given that the use of comparative advertising has been introduced so recently, UK courts are still determining the way comparative advertising laws are being put in

\footnotetext{
${ }^{11}$ The practice of favorable comparing one product whilst denigrating its competitor.

${ }^{12}$ Notice that, under the TMA, the plaintiff must prove that the use of its trademark by the advertiser is not honest, while, under the Directive, the advertiser must furnish evidence as to the accuracy of factual claims in the ad.
} 
practice. Several cases in the recent past suggest a general encouragement to the use of comparative advertising, as we will discuss in section 4 .

Berns Wright and Morgan (2002) compare the European Directive and the UK Trademark Law on one side with the FTC's statements and the Lanham Trademark Law on the other side. Some interesting points arise. In the FTC's law the focus of protection is only on consumers and competitors, while in the Directive it includes the general public as well. The comparative claim must compare "like with like" in UK, while the comparison of dissimilar product is permitted in the US. Moreover, objective claims are required in the UK while subjective claims are permitted in the US. Testing in a lawsuit must be ran by independent third party in UK, whereas standards are not set in the US. The burden of the proof as to the accuracy of factual claims in the ad is given to the advertisers in the UK, while it is given to the competitor challenging the claim in the US. ${ }^{13}$ Malicious intent must be proved in the UK for an ad to be actionable, this is in line with the "honest practice" the Court asks for, according to the TMA.

As a consequence, the comparison between the UK's and the US's attitude on comparison ad suggests for advertisers that since "[t]he American approach of aggressive, vague, opinionated comparisons is not likely to meet the standards under the European Directive, US advertisers should begin to utilize a more benign approach to comparative communications if they desire to present the same campaigns in EU Member States." (Berns Wright and Morgan, 2002, p. 22) ${ }^{14}$

As the analysis of some cases in section 4 will reveal, we are still far from a true harmonization of the way Directive 97/55/EC has been received by the different Member States. Given the different histories with respect to the legality of comparative advertising and different attitudes among member states, this is hardly surprising. ${ }^{15}$

\section{Particular industry study: professional services in EU}

It is interesting to note that the use of advertising in the market for professional services has traditionally been illegal in all industrialized countries. Today, where it is allowed,

\footnotetext{
13 The fact that the burden of the proof is given to the advertiser makes European advertising firms less likely and/or more cautious in using comparative advertising with respect to the American ones. This aspect is important in the economic analysis of comparative advertising as a signal of product quality, as we will show in the next section.

${ }^{14}$ Quite different regulatory regimes have also been adopted with respect to Internet advertising. In the US a comprehensive regulatory program is missing. Hence, the control is essentially left to the industries' self-regulation. In Europe competition policy sees the need to protect consumers from "aggressive business practice, while building trust and confidence in Internet information sources" (Berns Wright and Morgan, 2002, p. 23).

15 "It appears clear that, even if some useful general principles and criteria on comparative advertising have been achieved, many aspects are still assigned to the competence of national courts for case-by-case evaluation. No doubt that in the next future significant differences and contrasting solutions are likely to be found in the handling of similar or identical cases by domestic courts. The harmonizing process, which inspired the EU Directive on comparative advertising, will therefore require a substantial amount of case law - and for sure, additional interpretation by the European Court of Justice - before a satisfying level of uniformed criteria will result available.” (Hofer, 2003)
} 
usually advertising is legal as long as it is not comparative (see, for example, advertising regulation for lawyers in Sweden and in the US or the for accountants in Italy). ${ }^{16}$ However, it can be argued that such an advertising regulation for professional services seriously affects competition and is detrimental for consumers. The preamble of the Commission Communication of 9 February 2004 entitled "Report on competition in Professional Services" explicitly asks to regulatory authorities in the Member States and professional bodies to review the rules governing professional services because these rules are not necessary for the public interest and, thus, are unjustified. Moreover, the Commission suggests to put in place pro-competitive and transparency-enhancing mechanisms to strengthen consumer empowerment. ${ }^{17}$

Analyzing the markets in which lawyers, notaries, accountants, architects, engineers and pharmacists operate in the European Union, the Commission has identified five main categories of national legislation or self-regulation that restrict competition: fixed prices, recommended prices, advertising restrictions, entry restrictions and reserved tasks and regulations governing business structure and multidisciplinary practices. The Commission believes that advertising, and in particular comparative advertising, can be a crucial competitive tool for new firms entering the market and for existing firms to launch new products.

It is interesting to notice that advertising restrictions are justified by professional bodies on the ground of the asymmetry of information between practitioners and consumers of professional services. According to this argument, consumers find it difficult to assess information about professional services and therefore need particular protection from misleading or manipulative claims. Against such a rationale for advertising bans the Commission mentions the increasing body of empirical evidence which highlights the potentially negative effects of some advertising restrictions (see Stephen and Love 2000). This research suggests that advertising restrictions may under certain circumstances increase the fees for professional services without having a positive effect on the quality of those services. As the Commission argues, the implication of these findings is that advertising restrictions do not necessarily provide an appropriate response to asymmetry of information in professional services. Conversely, truthful and objective advertising may actually help consumers to overcome the asymmetry and to make more informed purchasing decisions (we return to this point in section 3).

\footnotetext{
16 "A large number of the EU professions are subject to sector-specific advertising regulation. In some cases (e.g. in France for notaries), advertising of any kind is prohibited. In others, specific media or advertising methods such as radio advertising, television advertising, "cold calling" or specific types of advertising content are prohibited. In certain cases, there is a lack of clarity in existing advertising regulations which, in itself, may deter professionals from employing certain advertising methods" (from the Commission Communication of 9 February 2004 entitled "Report on competition in Professional Services", page 14)

${ }^{17}$ From an enforcement perspective, since May 2004 the national competition authorities and the national courts have a more prominent role in assessing the legality of rules and regulations in the professions.
} 
The Commission reports that during the last two decades a number of member states have started to relax advertising restrictions in the professions. ${ }^{18}$ This general practice together with the market outcomes it has led to, suggests that sector specific advertising restrictions in these professions may not be essential for protecting consumers from misleading claims. As a result, today the legal, notary and pharmacy professions are able to conduct most forms of advertising in a number of Member States. Obviously all professions remain subject to general legislation that prevents untruthful or deceptive advertising.

\section{Economic Perspectives on Comparative Advertising}

It is useful to distinguish between different types of advertising: persuasive advertising, advertising as a complement, directly informative advertising, and indirectly informative advertising (see also Bagwell, 2003). Comparative advertising may be of any of these types.

Under persuasive advertising, advertising changes the preferences of consumers. This is the classic view of advertising and may also apply to comparative advertising. In the case of comparative advertising it may do so in two ways, it may increase the willingness-to-pay for the sponsoring brand and it may reduce the willingness-to-pay for the compared brand. Comparative advertising may also be seen as a complement if consumers derive benefits from consuming the advertising together with the product of the sponsoring brand. Also, when the comparative advertising is consumed together with the negatively compared good, it may decrease the utility that consumers of the competitor's product get from such a product. As shown in the case of non-comparative advertising, it is a matter of interpretation whether advertising is to be seen as persuasive or as a complement because market outcomes are the same (see Bagwell, 2003). However, welfare results may differ.

Concerning informative advertising, some specifications are useful. In the real world we observe both advertising messages which are content-based and whose words transmit information to consumers about the sponsoring product, and ads which, on the contrary are content-free. We consider content-based ads as potentially directly informative. In the case of content-free ads, the "words" of the advertising claim (if any) provide no information to consumers. The standard assumption is that consumers can infer the cost of the ad. The term "dissipative advertising" indicates that it is just the cost of the ad, instead of its content, which is able to transmit some information to consumers. The firm burns money in the advertising campaign and this is publicly observable; the

\footnotetext{
18 "In the 1970s, for example, advertising restrictions were removed for the legal and accountancy professions in the United Kingdom. In the 1990s, restrictive advertising rules were removed for the legal, accountancy and architectural professions in Denmark. In the last few years, strict advertising bans have also been relaxed for the professions in Germany. The accountancy and technical professions now function effectively without the need for any significant sector-specific advertising restrictions in a large number of Member States.” (again from COM2004 83 final, page 14)
} 
consequence is that advertising expenses can act as a signal for consumers (Nelson, 1976). ${ }^{19}$ In this sense, content-free ads can be indirectly informative. Under such indirectly informative advertising, the sponsoring firm does not necessarily give truthful information. By the amount of the advertising expenditure the firm may be able to convince consumers that its claims are truthful.

Comparative advertising can be considered content-based because it makes a comparison or a "superiority claim". In fact, implicitly or explicitly, in every comparative ad either the message "my product is better than ..." or "my product is as good as ..." is contained. Thus, a comparison ad is always potentially directly informative. The comparisons often serve as benchmarking to help consumers placing the product in the right category and focusing on its salient aspects. In fact, e.g. in the case of food advertising, absolute statements on nutrition often are of little information to consumers. As we will see in this section, comparative advertising can also transmit some information indirectly. First, the cost of the advertising campaign, as in the case of generic content-free ads, can indirectly transmit some information to consumers. What seems to be really relevant in the case of comparative ads is a second channel to indirectly convey information which operates through the competitor's reaction that a comparative ad potentially induces. Note that in general all advertising claims can be challenged. However, as outlined above for puffery, certain comparative ads are more likely to be challenged than corresponding non-comparative ads. ${ }^{20} \mathrm{We}$ will focus on this aspect later on in this section.

The superiority claim always contained in the comparative ad can go together with other direct information. This is the case of pricing comparative advertising where information about a verifiable characteristic of the product (and of the competitor's one) as the price, is given. Even when the information contained in the comparative ad is verifiable, legal disputes are frequent. Litigations often concern the way facts are presented in the claim and/or perceived by consumers, sometimes the facts themselves. The high number of legal issues proves that the second channel of indirect information, that is the competitor's reaction to the comparison ad, is important also in comparative ad with verifiable information. Nevertheless, a large part of comparative advertising, at least in the US, apart the (implicit) superiority claim, do not provide other direct information. Or, in other words, the statement in the ad is so vague, general and not

\footnotetext{
${ }^{19}$ Nelson's well known explanation of advertising as a rational phenomenon is based on the idea that its explicitly high cost works as a device to signal high quality of a brand. The signaling motive filled a gap in the understanding of a controversial economic phenomenon, namely the apparently wasteful advertising campaigns. The argument, intended to apply to generic advertising, implies that the cost, and not the content, of an ad is what really matters.

${ }^{20}$ This point is well taken by practitioners. Several advertising agency publish sentences on their web sites such as "Comparative advertising can be a very effective tool, but with it comes the risk of challenges by competitors, state attorneys general, and even the FTC". Or: "Comparative advertising campaigns present greater risks - and can lead to greater rewards in the form of customers response - than traditional monadic campaigns. You should assume that any campaign you run will be seen by your competitors' upper management, who will decide whether or not to challenge the ad". (Freeman and Nemiroff, 2001).
} 
verifiable, that the message conveyed by the ad only depends on the way consumers interpret it. Here, in the case the competitor named in the comparison ad goes to court, uncertainty concerning the court's judgment is really high. The litigation outcome substantially depends on the attitude towards comparative advertising which characterizes the court and the country where the dispute is ran.

Below we discuss comparative price advertising, persuasive advertising and informative advertising in more detail.

\section{Comparative Price Advertising}

Perhaps the most obvious case of comparative advertising is comparative price advertising. Competition authorities had in particular this type of advertising in mind when they started encouraging the use of comparative advertising. In fact, claims about price are easily verifiable, perhaps they represent the simplest type of direct information, as holds more generally for search good attributes. For this reason, in the case of comparative price advertising, not only competitors named in the ad file complaints against it, also many consumers who feel mislead react (e.g. in the Report from the Commission to the Council and the European Parliament on Consumer Complaints in Respect of Distance Selling and Comparative Advertising it is written: "Complaints from competitors refer to comparative advertising considered misleading and/or unfair. The complaints relate to comparisons based on price or price-levels. Complaints regarding comparisons in terms of quality are rarer, however." (COM(2000)127final).

Note that in its pure form comparative price advertising means that consumers are aware before the advertising is placed that products are the same (or comparable) and that they only lack price information. In this case, a comparison ad allows consumers to avoid costly search or if they were not going to search, to purchase the good at a lower price in expected terms. More price information is generally thought to intensify competition, which further reduces the expected price consumers pay. However, often the price comparison comes with a low-price guarantee. As is well-known in the literature on price-matching policies, such policies can lead to collusive outcomes, which is clearly detrimental to consumer welfare and, typically, also total welfare (e.g. Doyle, 1988, Logan and Lutter, 1989). Thus it is important to separate the issue of comparative price advertising from commitments to offer low prices. In the former case, the use of comparative advertising is likely to result in lower prices and less market power by firms. This is increases welfare. In the latter case, firms may effectively collude in prices. This reduces welfare. Related, if a firm acquires the reputation to use comparative price advertising together with undercutting against new rivals, any potential rival may want to stay outside the market.

Notice that, when comparative price advertising is performed on the Internet, the comparative claims should be easily verifiable by consumers who search a product at the lowest cost on the web. Thus, as a consequence of Bertrand competition, we should expect pricing at the marginal cost to be frequently reached for homogenous products. A 
recent empirical literature on E-commerce and Internet price strategies show that this is not necessarily true. In fact, firms frequently adopt obfuscation strategies and, as a result, price heterogeneity for homogenous goods is the general outcome. It is argued that a crucial role is exerted by shop-boots who have interest in maintaining such a price dispersion on the web (see e.g. Baye and Morgan, 2001).

\section{Persuasive Advertising: Comparative Advertising of Product Characteristics}

In many industries with branded consumer goods, the branded good is sold in a vertically integrated structure or the manufacturer essentially controls the downstream pricing. In these cases it is appropriate not to model any retailers or intermediaries and to postulate that manufacturers sell directly to consumers. In such a setting, Aluf and Shy (2001) present a duopoly model of persuasive advertising in which advertising by one firm reduces the willingness-to-pay for the competitor's product; this may correspond to negative comparative advertising. Advertising is assumed to increase the heterogeneity among consumers and thus product differentiation. Consequently, firms use "comparative" advertising as a product differentiation strategy, which reduces price competition. In a simple model with inelastic demand, welfare consequences are captured by the socially wasteful advertising expenditures. ${ }^{21}$

In several industries retailers or intermediaries play an essential role in selling a manufacturer's product to consumers. Shaffer and Zettelmeyer (2002) analyze the effects of a manufacturer's advertising campaign on the retailer under the assumption that comparative advertising leads to an increase of consumer valuations of the advertised product and a decrease of the consumer valuations for the compared product, where the advertising campaign can be tailored to mainly affect the valuations of the core or non-core consumers of one product. However, a retailer may not necessarily like comparative advertising if he carries also the product that would loose market share as a consequence of the comparative advertising campaign. If the retailer has market power he may refuse to participate in the campaign for the product for which the comparative advertising campaign is launched. Shaffer and Zettelmeyer explore the retailer's incentives not to participate in the advertising campaign. They find that participation is more likely the larger is the increase in consumers' valuations of the praised product relative to the decrease in their valuations for the product of comparison. They also find that the type of targeting of the advertising campaign is crucial in determining whether or not a retailer benefits from the manufacturer's campaign. In particular, a retailer always loses from ads that are targeted at the manufacturer's core consumers and always gains from ads that are targeted at the manufacturer's non-core consumers. The intuition is that after a campaign targeted at core consumers both manufacturers enjoy

\footnotetext{
${ }^{21}$ Quite differently, Shy (1992) and (1995, chap. 11) focus on the matching of heterogeneous consumers with differentiated brands, where the firms sell the branded goods over time and compete on market shares. In his model the two firms can use either non-comparative or comparative advertising. In Shy's terms, a non-comparative advertising is persuasive since it is aimed to attract new users. In contrast a comparative advertising is informative and is targeted to experienced users: it is used to inform those consumers who have already purchased the product before. By assumption, informative advertising cannot be misleading.
} 
more market power, whereas the reverse holds if the campaign is targeted at non-core consumers.

In these papers with persuasive advertising, it is implicitly assumed that comparative advertising affects consumers' valuation differently than non-comparative advertising. This reflects the view that consumers can make relative judgments but that they often find it hard to interpret information without a reference point. These analyses apply to products that are well established so that their qualities are known. Nevertheless, advertising changes consumers' preferences. An alternative view is to see advertising as a complement to other product characteristics. Also in this case comparative advertising increases the consumers' valuations of the advertised product and possibly decreases the consumers' valuations of the compared product. As mentioned above, the positive analysis under both views coincides. However, welfare consequences are different. For a welfare analysis of persuasive advertising see Dixit and Norman (1978).

\section{Informative Advertising: Comparative Advertising of Product Characteristics}

In new product markets, consumers often do not know the quality or other product characteristics of entering firms. In such cases, comparative advertising may be a useful strategy to transmit information to consumers. Advertising in general may be a tool to make consumers aware of a certain product (e.g. as modeled in Grossman and Shapiro, 1984). Comparative advertising can, in addition, establish a product in a certain segment of the market. For instance, to compete against an up-market car such as a BMW a car manufacturer has to position its own car as being comparable in certain product characteristics to cars in the targeted segment. In this case comparative advertising is simply directly informative advertising about availability and potentially product characteristics.

When the claim in a comparative advertising is easily (ex-post) verifiable and deviations from the truth are severely punished, a firm never misleads consumers. As a consequence we can assume that comparative claims are truthful and, thus, directly informative. Similar to the case with persuasive advertising (as in Aluf and Shy, 2001), it is conceivable that also directly informative comparative advertising relaxes price competition. Suppose that consumers do not observe the product characteristics and that firms may via truthful comparative advertising highlight the superiority of their product along certain dimensions. To illustrate this point, we consider a simple symmetric setting in which the firms' products can be positioned either at 0 or 1 and consumers have different evaluations for products at these two points. That is, consider a simple Hotelling specification of the market. In the linear Hotelling version with disutility parameter $t$ a consumer has an expected disutility of $t / 2$ for each product if the probability for each configuration 0 or 1 is $1 / 2$. Products of the two firms are ex ante identical so that price competition between the two firms is intense.

Consider now the possibility of comparative advertising in which firms can communicate the relative position of their products. Suppose that the realization of each 
product is 0 or 1 with probability $1 / 2$ each and that draws are independent. Then there is a 50 percent chance that products are differentiated. In this case it is profitable for firms to communicate their difference to consumers as this allows them to relax price competition. Hence comparative advertising may be a successful product differentiation strategy. The general idea by competition authorities that more information increases competition is here violated. The reason is that the relevant information released makes products distinguishable from each other, which increases the market power of the firms involved. The argument can also be made in a market in which firms have different qualities (for a formal analysis of this point see Barigozzi and Peitz, 2004).

One lesson of this paper is that more information in the market can lead to less competition. In its 1979 statement the FTC emphasized the opposite possibility, namely that more information can lead to more competition. This depends on whether information reduces or increases the market power of firms. In Barigozzi and Peitz (2004) comparative advertising can be seen as a differentiation strategy. The resulting higher price necessarily reduce consumer welfare; they also reduce social welfare, i.e. total surplus, if total demand is not perfectly price inelastic. There is, however, a countervailing welfare effect: the additional information in the market that is transmitted through comparative advertising improves the matching between product and buyers. The overall effect of social welfare depends on the degree of price elasticity of demand.

When comparative claims are directly informative, firms spends in the advertising campaign the minimum amount needed to transmit the desired information to consumers. However, when the claim in the ad is difficult to verify, in particular, when it contains a quality comparison, it seems important to consider how a manufacturer endogenously decides whether to use a truthful comparative claim or not, and how to spend for it, given the antitrust law and the way such a law is implemented.

For this consider a simple setup in which manufacturing firms sell directly to consumers. In the following setting comparative advertising has two characteristics: it is interpreted as a comparison quality claim and it is dissipative. The quality claim is verifiable only by a court and the ad transmits information indirectly both trough its cost and trough the competitor's reaction that it eventually induces.

Suppose an established and a new firm operate in a market. Consumers do not know the product quality of the new firm, whereas both firms do. The entrant's quality is either high $(H)$ or low $(L)$. Producing high quality leads to fixed costs $F$, producing low quality leads to zero fixed costs, while variable costs are zero for both qualities. It is commonly known which quality the established firm offers. Without loss of generality, it is assumed that this quality is high. Profits of the established firm depend on its own quality (always $H$ ) and consumer beliefs about the product quality of the new firm $q^{e}$. Given high quality of the established firm its reduced profits are written as $\Pi_{\mathrm{I}}\left(q^{e}\right)$. Given the quality of the established firm profits of the new firm depend on its true quality $q_{E}$ and its perceived quality $q^{e}$. Reduced profits are written as $\Pi_{\mathrm{E}}\left(q^{e}, q\right)$. Note in particular 
that $\Pi_{\mathrm{E}}\left(q^{e}, H\right)=\Pi_{\mathrm{E}}\left(q^{e}, L\right)-F$. The established firm's profits are decreasing in the competitor's perceived quality. In particular, $\Pi_{\mathrm{I}}(L)>\Pi_{\mathrm{I}}(H)$. The new firm makes higher profits the higher its perceived quality. In particular, $\Pi_{\mathrm{E}}(H, q)>\Pi_{\mathrm{E}}(L, q)$.

The two firms interact as follows. At the first stage, the product quality of the new firm is exogenously determined (for illustration: the quality is $H$ with probability $1 / 2$, and $L$ with probability 1/2). Both firms observe the quality of the new firm, consumers do not. At the second stage, the entrant decides among the set of advertising types $\{c, g, n\}$, namely comparative, generic, or no advertising respectively. Associated costs are $A_{c}, A_{g}$ and 0 , respectively. We assume, for simplicity, that after choosing $g$ or $c$ the advertising cost is unavoidable and can only take a given value $A_{c}=A_{g}=A$; this emphasizes that technically the two types of advertising differ only in the "wording" of the message but that the same advertising space has to be bought. At stage 3, provided that the new firm has used comparative advertising, the established firm decides whether to go to court, paying legal costs $C$. The court verifies the quality of the new firm and thus whether its claim was justified. If it was not justified the new firm has to pay damages $D$. At the last stage, consumers observe the decisions on stages 2 to 3 (including the court verdict) but not the realization of quality at stage 1 , and update their beliefs concerning the product quality of the new firm based on the observed actions in stages 2 and 3 . Then they make their purchasing decisions.

To have a meaningful analysis, suppose that the new firm gains from generic advertising if this makes consumers believe in high quality, $\Pi_{\mathrm{E}}(H, q)-\mathrm{A}>\Pi_{\mathrm{E}}(L, q)$. While this makes generic ads possibly attractive, it also implies that there does not exist an equilibrium (to be precise, perfect Bayesian equilibrium) in which the new firm uses generic advertising.

This can be seen as follows. At a potential separating equilibrium with generic advertising, an entrant firm with low quality type does not use advertising, that is, the decision at stage 2 is $n$, whereas an entrant firm with high quality type chooses generic advertising $g$ and forcibly pays A. The separation constraint for the low type is $\Pi_{\mathrm{E}}(L, L)$ $\geq \Pi_{\mathrm{E}}(H, L)-\mathrm{A}$. For the high type it is $\Pi_{\mathrm{E}}(L, H) \leq \Pi_{\mathrm{E}}(H, H)-\mathrm{A}$. Therefore, a separating equilibrium could exist only if the interior of the interval for A given by $\Pi_{\mathrm{E}}(H, L)-$ $\Pi_{\mathrm{E}}(L, L) \leq \mathrm{A} \leq \Pi_{\mathrm{E}}(H, H)-\Pi_{\mathrm{E}}(L, H)$ was not empty, which is impossible considering that the assumption on the cost of quality implies $\Pi_{\mathrm{E}}\left(q^{e}, H\right)=\Pi_{\mathrm{E}}\left(q^{e}, L\right)-\mathrm{F}$.

Does comparative advertising suffer the same fate? Not necessarily. Suppose that using comparative advertising (choosing $c$ at stage 2) makes consumers believe in high quality unless the court verdict contradicts the advertising claims. The separating constraint for a high type entrant is again $\Pi_{\mathrm{E}}(H, H)-A>\Pi_{\mathrm{E}}(L, H)$. Suppose furthermore that the established firm makes higher profits unmasking its competitor to be of low quality and receiving damages than it would make under high quality beliefs, namely $\Pi_{\mathrm{I}}(L)-\mathrm{C}+\mathrm{D}>\Pi_{\mathrm{I}}(H)$. When the incumbent reacts to a false claim, the separating constraint for an entrant of type $L$ is $\Pi_{\mathrm{E}}(L, L)-\mathrm{A}-\mathrm{D} \leq \Pi_{\mathrm{E}}(L, L)$, which is trivially satisfied. Since $\Pi_{\mathrm{I}}(L)>\Pi_{\mathrm{I}}(H)$ holds by assumption, a separating equilibrium with 
comparative advertising necessarily exists if $\mathrm{D}>\mathrm{C}$ and for sufficiently low cost of advertising, namely for $\Pi_{\mathrm{E}}(H, H)-\Pi_{\mathrm{E}}(L, H)>A$. This is the only possible separating perfect Bayesian equilibrium. Note that the damages may even be zero, $\mathrm{D}=0$, and the argument may still hold.

Alternatively, suppose that consumers do not observe the court action but only the choice of the advertising type at the second stage. It can be easily show that, comparative advertising solves the adverse selection problem verifying the selfselection constraints if and only if $\mathrm{D}>\mathrm{C}$.

From the analysis above follow a number of observations. First, comparative advertising may be an effective way to transmit information to consumers under circumstances under which generic advertising cannot serve as a signal of product quality. Second, the amount of damages needed to punish deceptive advertising depends on the speed of information acquisition by consumers. In the extreme case, where the court's verdict is observed before any purchases have occurred no damages may need to be awarded. In the other extreme case, where neither the incumbents reaction nor the court's verdict is observed by consumers, at least the direct and indirect legal costs of the incumbent have to be paid back by the entrant to provide the right incentives to the incumbent to sue in case of deceptive advertising.

The general idea behind the example is that comparative advertising triggers strategic interaction between informed parties. This interaction allows the uniformed party (consumers) to infer about the realization of an unobservable variable (product quality). There are two channels through which the incumbent's strategy may help the entrant. First, the choice of comparative advertising is interpreted by consumers as a stronger signal than generic because it would lead to legal action and payment of damages in case of cheating. Further, the observation of the informed incumbent not reacting to comparative claims is interpretable as good news about the entrant's quality. As stated above, the first channel may operate with or without the second.

Barigozzi, Garella, and Peitz (2003) provide a detailed analysis of a much richer model. Here firms receive a noisy signal about the entrant's product quality. In their model it depends on the parameter constellation whether comparative or generic advertising is the preferred signal. In particular, comparative advertising is likely to be used in markets in which firms receive precise information about product quality whereas in markets with imprecise information an entrant firm may be discouraged from making comparative claims because with some positive probability, they will turn out to be false provided the incumbent goes to court. Then, if damages are sufficiently high, the incumbent has indeed an incentive to challenge any comparative claim. In effect the entrant may opt for generic advertising that avoids the challenge.

This extended model also allows to distinguish between erroneous claims according to which the entrant acted in good faith and malicious falsehood. In the latter case, the entrant is perfectly aware that its quality claim lacks any substance. In equilibrium, the 
entrant makes erroneous claims but malicious falsehood can be wiped out. Note that in practice, US courts award higher damages in case of malicious falsehood. This suggests that judges are aware of the importance to separate erroneous claims from malicious falsehood. To do so they have to consider the intent of a firm. A harsh punishment of erroneous claims would lead to a higher risk using comparative advertising. This may then lead to less information in the market or to information transmission at a higher social cost as in the case of generic advertising. In the present context this is often not desirable from a social point of view (see below). If on the other hand malicious falsehood can be proven the court should punish such behavior.

In a more general setting, also the issue of price signaling arises. The classic treatments of advertising as a signal are within a monopoly set-up (e.g. Milgrom and Roberts, 1986; for an overview see Bagwell, 2003). Barigozzi, Garella, and Peitz (2004) show that a new firm will use advertising as a signal of quality when competing against an established firm together with price. Since comparative advertising reduces the amount of advertising expenses needed to separate, there is still a role for comparative advertising when prices are viable signals as well.

Since dissipative advertising expenditures have a welfare reduction as its direct effect, lower expenditures are, all else being equal, welfare-enhancing. Hence the direct effect of comparative compared to generic advertising is positive. If in the market equilibrium the threat to sue the sponsoring firm is never carried out, then the possibility to go to court only disciplines a firm that might want to make false claims. In effect, the signaling cost of advertising is lower and welfare is improved. However, if the precision of the information available to the sponsoring brand is imperfect, the sponsoring firm may run a comparative advertising campaign in the belief that its claims are truthful whereas effectively they are not. Then two situations can arise depending on the information of the competitor. First, if both firms have access to the same information, the competitor may sue regardless of the information it possesses given that there is always some chance that the court will rule the advertising claim to be wrong. If this is sufficiently likely and the competitor's benefit associated to go to court are sufficiently high (through damages and the indirect effect of information revelation to consumers), it is clearly in the interest of the competitor to take this action. Second, if the competitor has access to different sources of information than the sponsoring firm and if this information tells that the claim is false, it will go to court even if the benefit associated to this action is modest. In these cases, litigation is not only costly for the parties involved but often adds a social cost if the cost generated by the case on the court system is not fully covered by the two involved parties, the sponsoring firm and its competitor. This negative effect on social welfare has to be taken into account. On the positive side, the court generates possibly new information that consumers may use when making their purchase decision.

It is interesting to notice that the signaling role of dissipative advertising is of particular importance in the case of experience and credence goods. For such goods quality claims are not verifiable to the consumer. In the case of experience goods, a consumer must 
consume these goods before knowing if the product characteristics fit her taste. Dissipative advertising has a positive effect in that it may allow high quality firms to transmit some information to consumers about their product characteristics, in particular if there are repeat purchases. Comparative advertising can have the same positive effect, but at a lower cost to the advertising firm.

Information asymmetry between experts and consumers is higher in the case of credence goods. For such goods consumers cannot learn quality after consumption. As we explained in section 2, professionals argue that (comparative) advertising must be forbidden in the consumers' interest. In fact in their opinion consumers find it difficult to assess information about professional services and therefore need particular protection from misleading or manipulative claims. It is true that generic dissipative advertising cannot be, in this case, a channel of indirectly transmitting information because information is not ex-post verifiable. Anyway, the second channel of indirect information, that is, the exposition to the competitor's reaction is still present with credence goods, provided that also competitors and the courts can become experts. This may enable a firm to transmit some information to consumers. Hence, we have provided a theoretical argument in support of the use of comparative advertising for professional services.

\section{Analysis of Selected Antitrust Cases}

\section{Allegedly misleading comparative advertising}

Several European and US cases have as a critical issue whether the comparison ad is indeed misleading. In the UK as well as in the US case law has evolved which provide interpretations of the law and thus additional guidance. As we mentioned in section 2, in the UK section 10(6) of the 1994 Trademark Act is relevant for the case analysis of comparative advertising. According to section 10(6) the use of a registered mark does not constitute copyright infringement if it is in accordance with honest practices in industrial and commercial matters. The term "honest practices in industrial and commercial matters" can be criticized as vague. It may be interpreted by bodies that regulate advertising. However, in Barclays Bank Plc v RBS Advanta [1996] RPC 307 the court did not consider the suggestion to follow statutory or agreed codes of conduct.

Barclays Bank Plc $v$ RBS Advanta concerned advertising by RBS Advanta. ${ }^{22}$ It compared the terms of the advertiser's own credit cards with those of competing credit cards including the Barclaycard Standard Visa. A leaflet listed 15 dimensions summarized by the statement that the RBS Advanta card was said to be 'a better credit card all round'. In addition, a brochure included a comparative table showing the main financial terms of competitive credit cards.

The plaintiff Barklay's Bank argued that the leaflet was not honest as it did not compare like with like. In particular, it was selective because it did not mention other ancillary

\footnotetext{
${ }^{22}$ Our presentation of this case follows Swan (2000).
} 
benefits which Barklay's Bank offered to its cardholders and which RBS Advanta did not. Examples are a 24 hour emergency service and an overseas emergency service. Furthermore, 6 or 7 out of the 15 points listed in the RBS Advanta leaflet were common to Barclaycard as well.

Judge Laddie $\mathrm{J}$ was not convinced and concluded that the defendant really believed to offer customers a better deal, summarized by the advertisements with the list of 15 items. He argued that honesty had to be judged by what can be reasonably expected by the relevant public exposed to the advertisements.

Subsequent decisions have made it clear that the use of a competitive trade mark is acceptable if it is honest. In the words of Laddie $\mathrm{J}$, an advertisement may be dishonest if it is "significantly misleading".

The general principles have been summarized by judge Jacob $\mathrm{J}$ in Cable \& Wireless PLC v. British Telecommunications PLC [1998] FSR $383::^{23}$ "The primary objective of s.10(6) of the 1994 Act is to permit comparative advertising.

1. As long as the use of a competitor's mark is honest, there is nothing wrong in telling the public of the relative merits of competing goods or services and using registered trade marks to identify them.

2. The onus is on the registered proprietor to show that the factors indicated in the proviso to $\mathrm{s} 10(6)$ exist.

3. There will be no trade mark infringement unless the use of the registered mark is not in accordance with honest practices.

4. The test is objective: would a reasonable reader be likely to say, upon being given the full facts, that the advertisement is not honest?

5. Statutory or industry agreed codes of conduct are not a helpful guide as to whether an advertisement is honest for the purposes of s. 10(6). Honesty has to be gauged against what is reasonably to be expected by the relevant public of advertisements for the goods or services in issue.

6. It should be borne in mind that the general public are used to the ways of advertisers and expects hyperbole.

7. The 1994 Act does not impose on the courts an obligation to try and enforce through the back door of trade mark legislation a more puritanical standard than the general public would expect from advertising copy.

8. An advertisement which is significantly misleading is not honest for the purposes of s. 10(6).

9. The advertisement must be considered as a whole.

10. As a purpose of the 1994 Act is positively to permit comparative advertising, the court should not hold words used in the advertisement to be seriously misleading

\footnotetext{
${ }^{23}$ These were established by established in Barclays Bank v. RBS Adanta and the subsequent case of Vodafone Group plc v Orange Personal Communications Services Ltd [1997] FSR 34. Jacob J built on M. Crystal QC in British Telecommunications Plc v AT \& T Communications (UK) Ltd (unreported) 18 December 1996.
} 
for interlocutory purposes unless on a fair reading of them in their context and against the background of the advertisement as a whole they can really be said to justify that description.

11. A minute textual examination is not something upon which the reasonable reader of an advertisement would embark.

12. The court should therefore not encourage a microscopic approach to the construction of a comparative advertisement on a motion for interlocutory relief."

This view has been restated in British Airways plc $v$ Ryanair Limited [2000] which contrasts nicely with a court's view of an advertising campaign by Ryanair in Belgium. We first consider the case in Britain before turning to the case in Belgium.

In 1999 Ryanair ran a comparative advertising campaign in various newspapers in the UK. First, it placed the so-called "Bastard" advertisement (with the headline "EXPENSIVE BA...DS!), later the so-called "Expensive" advertisement (with the headline "EXPENSIVE BA"). I reproduce them as an annex to this judgment. The Bastard advertisement appeared in February and March in several national newparpers the Expensive advertisement appeared just once in November, in the Evening Standard. Before the latter the Advertising Standards Authority had upheld a complaint by members of the public (not made by BA) against the Bastard advertisement. It considered that the headline "was likely to cause serious or widespread offence." Ryanair responded that it would not use the headline again. The court then only had to decide how costs of the two sides were to be allocated; both sides made the case on a matter of high principle.

In British Airways plc v. Ryanair Limited, 8 December 2000, the judge gave a general evaluation about what constitutes misleading advertising. He comments on the testimonies as follows. "For Ryanair the principal witness was Mr Jeans, its Sales and Marketing Director. ... he wanted dramatically to convey the message that Ryanair was a lot cheaper than BA for what was broadly the same journey. In part the effect of that would be to take sales from BA, in part it would generate new sales from those who could not afford BA prices. In relation to the Bastards advertisement Mr Hobbs [for the plaintiff] sought to demonstrate that Ryanair selected the headline first and put in the price comparisons later as some sort of spurious justification for the headline. Actually the facts were that the advertising agency had been asked to produce a number of headlines (which they did somewhat sequentially). All of these were intended to go with a price comparison table - of the same sort as Ryanair had used previously. The fact that the detailed BA prices were only obtained at the last minute has no sinister significance - that would have happened whatever the headline chosen. The point of the last minute obtaining of detailed prices was to avoid the risk of any change happening before publication. It was done to ensure accuracy." (British Airways plc v. Ryanair Limited, 8 December 2000). The judge continues: "Before passing from the witnesses, it is particularly pertinent to observe that no witness testified to anyone actually being misled by either advertisement. There have been no complaints about deceptiveness in 
respect of any of the matters alleged made by members of the public (to whom the advertisements were directed) or even by anyone independent in the trade. Complaints might have been made to either party, to the ASA or to any Trading Standards Officer in any Local Authority."

BA had three complaints: (1) it found the Bastard headline offensive; (2) it said that the individual price comparisons were unfair; (3) and it said that in the case of Frankfurt and Dinard the destination comparisons were unfair. With respect to the headling Ryanair promised not to repeat it. Ryanair considered both the price comparison and the destination comparison to be fair. In the two latter points the judge agreed with Ryanair.

In the advertisements Raynair mentions only one price for BA and one for Ryanair for certain city-pairs. At that point BA operated like other "flag" or "conventional" airlines under the so-called "Saturday night rule", according to which to fly out on a weekday and fly back before the weekend, costs a lot more then taking a return-trip which includes a Saturday night. For example, in the BA's return same week fare from London to Frankfurt was, as quoted in the Bastard advertisement, £374; including Saturday night, the return fare would be $£ 192$. In its price comparison Ryanair noted that prices refer to "Midweek return fees", where Ryanair required a minimum of two nights stay on its flights. Although this term is to some extent ambiguous, the judge argued that "what matters is the phrase read in the context of the advertisement - by people familiar with the Saturday night rule. My conclusion is that most people would have appreciated that what was being got at was the resented rule." Furthermore, the judge reasoned as follows: "I think people would take the advertisement to be making the most favourable comparison Ryanair could reasonably make - that is what advertisers are most apt to do. The average consumer would know BA was cheaper if one stayed over Saturday. So, he would realise that it was same week returns that were being compared." This is in line with earlier cases according to which the consumers have an understanding of the way advertisers make their messages. In the words of Jacob J, "I do not think that the average consumer would find the price comparison misleading. He would expect there to be some sort of conditions (and indeed the small print makes that clear). In substance the advertisements were true."

With respect to destinations, there were two points. The first relates to Frankfurt. Ryanair fly to the "secondary" airport Frankfurt-Hahn which is designated by IATA as a city airport of Frankfurt but is about 68 miles from the city centre whereas Frankfurt International is only around 6 miles from the city center. BA correctly said that the advertisement did not make this clear, which was true. However Judge Jacob J did not consider this to be an unfair comparison. ${ }^{24}$ The second point relates to Dinard and was rather bizarre since a flight with BA would require to change planes. Hence, the ad compares the fares but does not point out that the BA fare is for a journey which suffers

\footnotetext{
${ }^{24}$ Interestingly, a German court required Ryanair to state that its airport is Frankfurt-Hahn not Frankfurt in its comparative ads comparing its prices to those of Lufthansa. The naïve observer might conclude that British consumers must be better informed about the airlines' use of German airports than German consumers.
} 
the additional disadvantage of having to change planes. This clearly does not make the advertisement by Ryanair dishonest, as argued by Jacob J.

Ryanair also ran advertising campaigns in continental Europe comparing its flights with those of flag carriers. Perhaps the most illuminating case is the one in Belgian, a country which traditionally has been hostile to comparative advertising. On 24 April 2001 advertisements with the text "Welcome Ryanair and its lowest fares. Goodbye Sabena and its outrageously expensive flights" appeared in 6 national Belgian newspapers and on publicity vehicles in Brussels. On the same day Sabena asked Ryanair to withdraw the ads. Ryanair ignored this request and on the following day released an ad with a picture of the Brussels landmark the "Mannequin Pis", a statue of a boy urinating, with the line " Pissed off with Sabena's high fares? Low fares have arrived in Belgium". Ryanair also published price comparisons indicating the vast difference between the two airlines' one-way fares. Sabena's president and CEO reacted by calling the ads "clearly defamatory". Raynair's CEO O'Leary faxed back that the ads were "valid criticisms of Sabena's outrageously high air fares" and, hoping for free publicity, distributed it to every major Belgian newspaper.

Sabena then took the case to court and claimed that the ads violated Belgian comparative advertising legislation and were unlawful because (1) the ads were misleading; (2) the text was denigrating and damaging to Sabena's reputation (3) Ryanair obtained unfair advantage through the use of Sabena's logo and trademark. The claim that the ads were misleading were based on the fact that Sabena offered services to many destinations whereas Ryanair offered flights to only four countries in Europe, at the time the ads were placed. Also, no comparisons of "relevant characteristics" were made. In particular, Sabena claimed that consumers could not objectively judge the services of Sabena and Ryanair based on the terms "lowest" or "outrageously expensive".

Ryanair defended its campaign as in the case against British Airways. It argued that the ads were not misleading. By launching its service to Brussels-Charleroi, Ryanair claimed that it had shown that lower air fares were possible. It also claimed that consumers had benefited overall as Sabena reduced its fares on routes where it was in competition with Ryanair.

Judge J M Lahaye (in a judgment of the Brussels Commercial Court published on 10 July 2001) upheld Sabena's complaint. He found that Ryanair's advertising campaign was misleading and offensive and damaged Sabena's reputation. He ruled that any future comparative ads by Ryanair should include details of prices and comparisons of the quality of service. Ryanair was ordered to discontinue the ads immediately and to run corrective ads: he ordered Ryanair to publish an an extract of the decision in Belgian newspapers and post it on its website for a period of three weeks. The court further imposed a penalty of 99,000 Euros for every future breach of the order. ${ }^{25}$

\footnotetext{
${ }^{25}$ Ryanair paced ads with an apology in Belgian newspapers. "We're Sooooo Sorry Sabena!" said the advert, which went on to list seven one-way price comparisons, maintaining that Ryanair is up to $89 \%$
} 
Both of these campaigns tried to establish RyanAir as a low-cost alternative to national "flag" carriers, BA in the UK and Sabena in Belgium. They show different attitudes of the courts within Europe. As mentioned in Section 2 Belgium has in the past (before the EU Directive became effective) taken a hostile stand towards comparative advertising, whereas comparative advertising has been seen more relaxed in the UK since the TMA of 1994. Even after the EU Directive was passed, the Belgian and UK court rulings suggest a difference in approaches. ${ }^{26}$

The fact that Belgium did not allow comparative advertising until recently and that its court appeared to be tougher on RyanAir allows for a number of alternative interpretations. Belgian courts may still be more hostile to comparative advertising because of legal history. Alternatively, in Belgium law makers and judges alike may have a more parternalistic vision according to which there are consumers who suffer from severe misperceptions and therefore have to be protected. In such a world, comparative advertising would need to adhere to the strictest standards. Perhaps the most favorable view is that at least initially the Belgian court feels it has to protect consumers from ads like the one by Ryanair because consumers lack the experience to see the ad in the same context as e.g. British consumers would do.

While the Belgian case highlights the high hurdle for comparative advertising in parts of continental Europe, standards for "honest" comparative advertising appear to be lower in other places.

This can be illustrated by a recent US Lanham Act case. In Avon Products v. S.C. Johnson \& Son (1994) $)^{27}$ the court refused to prohibit the comparative advertising for the insect repellent Off by Johnson. The ad stated that Off was better than Avon's Skin-SoSoft, a bath oil frequently used as insect repellent. Avon called Johnson's ads "illegal efforts to confuse consumers, tarnish Avon's reputation, and gain sales at Avon's expense." In particular, Avon claimed that the ad would confuse consumers because Avon had a new insect repellent. With the suit Avon tried to make Johnson stop the advertisements, issue corrective advertising, and provide monetary damages. The court was not troubled by Johnson's advertising campaign. ${ }^{28}$

cheaper. The ad concluded: "Ryanair is really, really sorry and promises to include this information in our future advertising." At the end of 2001 Sabena ceased to exist.

${ }^{26}$ RyanAir had more success against Alitalia in Italy than against Sabena in Belgium. In 2002 a ruling by Italy's Competition Authority rejected a complaint by Alitalia about Ryanair's comparative campaign. Ryanair's chief executive O'Leary commented: “Alitalia attacked Ryanair's comparative advertising precisely because it is true - and the Authority now confirmed it. The decision guarantees that Ryanair can continue to demonstrate the extent to which Alitalia is overcharging Italian consumers" (cited in The Daily Mirror, London; Sep 13, 2002).

${ }^{27}$ Avon Products, Inc. v. S.C. Johnson \& Son, Inc. (1994), 1994 U.S. Dist. LEXIS 7950, 94 Civ. 3958 (AGS) (S.D.N.Y. June 15)

${ }^{28}$ The only exception is that the court prohibited a footnote in the ad that contained the false claim that the competitor's product Skin-So-Soft was not registered with the Environmental Protection Agency as an insect repellent. 
In this case (as in several others) the comparison is rather ambiguous. Under the Lanham Act the plaintiff faces a high burden of proof. He has to show that consumers were likely to be misled by the ad. To do so, the plaintiff has to prove the actual messages that the ad communicates to consumers.

The courts in the US distinguish between establishment (or tests prove) claims and nonestablishment claims. In cases with non-establishment claims the plaintiff has to prove that the advertising is false. This is clearly a higher burden of proof than for case with establishment claims where plaintiff must only prove that the supporting tests are inadequate.

\section{Superiority or Puffery}

Our next two cases go one step further. In those cases it is not obvious whether the ad merely contains puffery or whether the claim can transmit some information to consumers.

In 2000 a federal judge ruled that Papa John's must pay over $\$ 468,000$ in damages to Pizza Hut and cease and desist from using its tag line "Better ingredients. Better pizza." The judge ruled in favor of Pizza Hut, as the ingredient comparison was misleading. In fact the claim cannot be scientifically substantiated nor taste tests exist that prove a statistically significant preference for Papa John's product. Notice that a claim would be a generalized statement of opinion, hence puffery, notwithstanding the clear implication that the advertiser's pizzas were better than others because of the better ingredients. However, in the context of two commercials that focused on the advertiser's ingredients, the court agreed that the slogan was an implied, unsubstantiated superiority claim with the characteristics of a statement of fact. However, the $5^{\text {th }}$ US Circuit Court of Appeals overturned the verdict. The court argued that Pizza Hut failed to present evidence that a reasonable consumer was influenced in her purchasing decision, that is, the plaintiff failed to show implied falsity. (In 2001, the US Supreme Court refused to review the decision.)

A recent case in a Dutch court suggests that comparative advertising with questionable superiority claims may survive European courts. In April 2004 a civil court in Utrecht, Netherlands, has ruled on a case concerning razor manufacturers Gillette and Wilkinson. The court decided that both can claim that their most recent bladed razors are the best. Gillette launched a complaint before the court because Wilkinson had advertised its new 4 bladed razor saying that it produces the smoothest result and that it had carried out comparative tests, showing that it was even better than Gillette's 3bladed one. Gillette sued Wilkinson claiming that this was misleading advertising. Wilkinson filed a counter suit, saying that also Gillette made superiority claims in its advertising, without being able to substantiate these claims. The court rejected Gillette's case arguing that the advertising was not misleading. It also rejected Wilkinson's case because Gillette simply used classic advertising exaggerations, which could not be seen as misleading. The court argued that consumers would not believe the ads anyway. 
Hence both firms can continue to claim that they are better than their competitor (for more information see BBC news, 23 April, 2004).

For the advertising not to be misleading, consumers must be either rather sophisticated or, since advertisers can exaggerate and use hyperbole, mostly ignore content. In the latter case there is hardly any possibility of a more efficient information transmission with comparative claims than with generic advertising. If consumers are not able to separate advertising which exaggerate to those which do not, firms have an incentive to exaggerate whenever they can get away with it. Although consumers can be expected to learn about the courts' stand on comparative advertising, by allowing exaggerations and hyperbole the courts may have made it more difficult to convey information for those advertisers who otherwise would have provided truthful content statements. This may lead to socially wasteful advertising and ultimately less information in the market. Therefore, the courts must distinguish very carefully between those cases in which the ad contains puffery which is easily recognized as such by the average consumer and other cases in which claims are potentially informative but the content is exaggerated. In the latter case, we would argue that courts apply strict test so as to make truthful nonexaggerated claims possible.

A case in point is S.C. Johnson v. The Corox Co., 241 F.3d $232\left(2^{\text {nd }}\right.$ Cir. 2001). In this case, Clorox, the maker of Glad-Lock storage bags, ran television that featured a comparative ad of Glad storage bags versus Ziploc storage bags. Both of them were filled with water and turned upside down. In the advertisement the Glad-Lock bags stayed watertight while the Ziploc bags leaked profusely. An animated goldfishin in the Ziploc bag was shown in a state of distress. To prove that the ads were misleading, S.C. Johnson simply proved that their bags leaked at a slower speed than the rate represented by the advertisement. The court concluded that the content of the ads was literally false and the ads were found in violations of section 43(a) of the Lanham Act. ${ }^{29}$

\section{Damages}

In our last case we consider damages. The most famous case of punitive damages in the US is the U-Haul International Inc. v. Jartran, Inc., 793 F.2d 1034 ( $9^{\text {th }}$ Cir. 1986). The court found Jartran of wilful and malicious false advertising after running a comparative advertising campaign run for more than a year. As the basis of the $\$ 40$ million judgement served $\$ 6,4$ million to cover the cost of the false advertising campaign and $\$ 13,6$ million to air corrective advertising. Under Section 35 of the Lanham Act, the court doubled the award to a total of $\$ 40$ million. (see e.g. Bixby and Lincoln, 1989, or Steinberg and Naidech, 2003). In this case awarding the defendant's profit was justified to avoid the defendant's unjust enrichment, as first established by the $2 \mathrm{~d}$ Circuit in 1984 for a case of false advertising (see Raymond, 2004). ${ }^{30}$

\footnotetext{
${ }^{29}$ Compared to the Pizza Hut case, this illustrates that literal falsity can be a more successful strategy for the plaintiff (see also section 2).

${ }^{30}$ Burndy Corp., v. Teledyne Industries Inc., 748 F.2d Cir. 1984.
} 
Damages in form of corrective advertising may be needed to re-establish the lost or damaged reputation of a firm. Furthermore, damages in form of attorney's fees are appropriate to give the plaintiff a sufficiently strong incentive to sue against comparative advertising which the plaintiff thinks to be misleading. Often, incentives to sue are sufficiently strong even in absence of such awarded damages (see Barigozzi, Garella, and Peitz, 2003). Also, for a campaign that has already generated revenues, lost profits may have to be rewarded to the competitor in case of false or misleading advertising. The corresponding incentives are amplified under punitive damages. In all cases of damages it seems important to distinguish between erroneous and malicious false claims. This allows firms that believe in their product to go ahead with their campaign even if to their surprise the claims prove to be erroneous (see our previous discussion in section 3).

\section{Conclusion}

Antitrust authorities encourage the use of comparative advertising because, if fair and not misleading, it conveys useful information to consumers and can increase competition in the market place. The way advertising affects consumers' behaviour is a on-going topic in the economics and marketing literature. In this paper we have concentrated on the interpretations of advertising proposed by economists and their application to comparative advertising.

The aspect of comparative advertising most relevant for antitrust authorities is its role in transmitting information to consumers. This is related to the important issue of how information can be transmitted by an "interested party" to another economic agent and rises the problem of credibility. There is an important difference between content-free generic advertising and comparative advertising: the latter contains a "superiority claim" which potentially induces the reaction of the competing firms. Competitors (implicitly or explicitly) mentioned in the ad decide whether to challenge the superiority claim by engaging in a lawsuit.

When a claim in a comparative ad is easily verifiable and deviation from the truth are severely punished, an advertising firm never misleads consumers. In this case we can argue that comparative claims are truthful and comparative advertising is directly informative. Under directly informative advertising Barigozzi, and Peitz (2004) show that comparative claims can become a differentiation strategy. In fact they can be used by competing firms to credibly highlight the superiority of their product along certain dimensions such to relax price competition. Hence, contrary to what competitions authorities seem to believe, it is possible that more information, as provided by comparative advertising, increases the market power of firms, instead of reducing it.

When the claim in the ad is difficult to verify, advertising firms endogenously decide whether to use truthful or false statements. In this case and as showed in Barigozzi, Garella and Peitz (2003), together with the cost of the advertising campaign, the potential reaction of the competitor can provide an efficient channel to indirectly 
transmit information to consumers. In fact, when running a false advertising campaign, the firm will be prosecuted and condemned. This represents a mimicking cost and slacks the incentive constraint for the advertising firm. Thus, by using (dissipative) comparative advertising, signalling can be obtained at a lower cost. The signalling role of comparative advertising is particularly important when the advertising claim in based on quality characteristics that consumers cannot verify before they purchase the good. Thus, comparative quality claims can be indirectly informative for consumers if false ads are punished, that is if the legal system works properly.

From Barigozzi, Garella and Peitz (2003) a second interesting lesson can be drawn: competition policies, antitrust laws and their implementation are essential in making a comparative advertising campaign credible. This is important because only if claims are credible, comparative advertising can convey some useful information to consumers. In other words, comparative ads can increase competition among firms and retailers only if claims are credible and claims are credible only if the legal system is efficient in processing false claims. If firms diffusing misleading ads are not punished, all claims become empty: comparative claims which are defined non actionable "mere puffery" becomes equivalent to generic ad and are not informative.

The way consumers interpret advertising is important for the court, as "implying falsity" claims prove. But, at the same time, consumers' perception is influenced by the legal practice, that is consumers learn to interpret comparative claim observing the outcome of existing litigations. In this sense legal practice deeply affects the way comparative advertising is used by firms and understood by consumers. Thus, a more restrictive legal attitude towards comparative claim, as we find in Europe can perhaps better improve competition than in the US because it contributes more to the credibility of comparative advertising. However, if consumers are sophisticated enough such that they distinguish between comparative advertising containing puffery, which cannot be sanctioned, and other comparative advertising claims, which can be sanctioned, also the legal attitude in the US does not interfere with the flow of information from firms to consumers. 


\section{References:}

Aluf, Y. and O. Shy, 2001, Comparison-Advertising and Competition, mimeo, University of Haifa.

Bagwell, K., 2003, The Economic Analysis of Advertising, forthcoming in: M. Armstrong and R. Porter (eds.), The Handbook of Industrial Organization, vol. 3, Amsterdam: North Holland.

Barigozzi, F., P. Garella, and M. Peitz, 2003, With a Little Help from my Enemy: Comparative versus Generic Advertising, mimeo.

Barigozzi, F., P. Garella, and M. Peitz, 2004, Prices and Advertising as Signals of Quality: Competing against a Renown Brand, mimeo.

Barigozzi, F. and M. Peitz, 2004, Informative Comparative Advertising and the Competitiveness of Markets, mimeo.

Barone, M. J. and P. W. Miniard, 1999, How and When Factual Ad Claims Mislead Consumers: Examining the Deceptive Consequences of Copy X Copy Interactions for Partial Comparative Advertisements , Journal of Marketing Research, 36, 58-74.

Baye, M. R. and J. Morgan, 2001, "Information Gatekeepers on the Internet and the Competitiveness of Homogeneous Product Markets." American Economic Review, Vol. 91(3), 454-474.

Berns Wright L. and F.W. Morgan, 2002, Comparative Advertising in the European Union and the United States: Legal and Managerial Issues, Journal of Euromarketing, 11(3), 7-31.

Bixby, M.B. and D. Lincoln, 1989, Legal Issues Surrounding the Use of Comparative Advertising: What the Non-Prescriptive Drug Industry Has Taught Us, Journal of Public Policy and Marketing 8, 134-160.

Commission Communication of 9 February 2004 entitled "Report on Competition in Professional Services" [COM(2004) 83 final]

Dickerson, J. and P. Jordan, 2003, Comparative Advertising - A Battle in the Skies, DLA, .

Dixit, A. and V. Norman, 1978, Advertising and welfare, Bell Journal of Economics 9, $1-17$.

Doyle, C., 1988, Different selling strategies in Bertrand oligopoly, Economics Letters 28, 387-390. 
Freeman, D.R. Jr and E. A. Nemiroff, 2001, We're Number 1: A Guide to Comparative Advertising, http://www.advertisinglawplaybook.com/documents/We are Number 1.pdf.

Gnepa, T., 1993, Observations: Comparative Advertising in Magazines: Nature, Frequency and a Test of the Underdog Hypothesis, Journal of Advertising Research, 70-75.

Grossman, G.M. and C. Shapiro, 1984, Informative advertising with differentiated products, Review of Economic Studies 51, 63-81.

Jain, S.P., B. Buchanan, D. Maheswaran, 1998, Comparative Versus Noncomparative Messages: the Moderating Impact of Pre-purchase Attribute Verifiability, Marketing Science Working Paper Series, William E. Simon School of Business, University of Rochester.

Kihlstrom, R. E., and M. H. Riordan, 1984, Advertising as a Signal, Journal of Political Economy 92, 427-50.

Hofer, F. 2003, Comparative Advertising in Europe: recent developments.

Leighton, R.J., 2004, Materiality and Puffing in Lanham Act False Advertising Cases: The Proofs, Presumptions, and Pretexts, Trademark Reporter 94(3), 585-633.

Logan, J. and R. Lutter, 1989, Guaranteed lowest price: do they facilitate collusion?, Economics Letters 31, 189-192.

McKenna, J. and W. Manning (2002), Lanham Act Also Applies to False Advertising Claims, National Law Review, May 13, 2002.

Milgrom, P. and J. Roberts, 1986, Price and Advertising Signals of Product Quality, Journal of Political Economy, 94, 796-821.

Muehling, D., J. Stoltman, and S. Grossbart, 1990, The Impact of Comparative Advertising on Levels of Message Involvement, Journal of Advertising , 19, 41-50.

Nelson, P., 1974, Advertising as Information , Journal of Political Economy 84, 729754.

Pechmann, C. and D.W. Stewart, 1990, The Effect of Comparative Advertising on Attention, Memory, and Purchase Intentions , Journal of Consumer Research, 17, 180191. 
Pechmann, C. and S. Ratneshwar, 1991, The Use of Comparative Advertising for Brand Positioning: Association versus Differentiation, Journal of Consumer Research, $18,145-160$.

Petty, R. and P. Spink, 1995, Comparative advertising law in the European Community: Will the proposed directive harmonize across the Atlantic?, Journal of Public Policy and Marketing, 14(2), 310-318.

Prasad, V.K., 1976, Communications-Effectiveness of Comparative Advertising: a Laboratory Analysis, Journal of Marketing Research, 13, 128-142.

Raymond P.D., 2004, Damage Control: What to do if you get sued over advertising, http://www.adlaw.com/rc/handbk/rf_damage.html.

Report from the Commission to the Council and the European Parliament on Consumer Complaints in Respect of Distance Selling and Comparative Advertising (Article 17 of Directive 97/7/EC on distance contracts and Article 2 of Directive 97/55/EC on comparative advertising) [COM(2000)127final]

Shaffer, G. and F. Zettelmeyer, 2002, Comparative Advertising and Retailer Participation, mimeo.

Shimp, T., 1990, Promotion Management and Marketing Communications, 2nd ed., Chicago, the Dryden Press.

Shimp, T. and D. Dyer, 1978, The Effects of Comparative Advertising Mediated by Market Position of Sponsoring Brand, Journal of Advertising 7, 13-19.

Shy, O., 1992, A Welfare Evaluation of Comparison Advertising, Tel Aviv Foerder Institute for Economic Research Working Paper 10/92.

Shy, O., 1995, Industrial Organization: Theory and Applications, Cambridge and London MIT Press.

Stephen, F.H. and J.H. Love, 2000, 'Regulation of the Legal Profession', in B. Bouckaert and G. De Geest (eds) Encyclopedia of Law and Economics, Volume III: The Regulation of Contracts, Cheltenham, p.987-1017.

Swan, C., 2000, Comparative Advertising Part 1: It's only Advertising, Intellectual Property Lawyer, August 2000, http://www.simkins.co.uk/articles/article167.aspx

Steinberg, L. B. and A. G. Naidech, 2003, Remedies Available for False Advertising under California Business \& Professions Code $\$ 17500$ and section 43(A) of the Lanham Act, http://www.adlawbyrequest.com/industry/LANHAM.shtml 
Wilkie, W.L. and P.W. Farris, 1975, Comparison Advertising: Problems and Potential, Journal of Marketing, 39, 7-15.

Wood, D. (2003), Strategies for In-House Legal Counsel in Bringing or Resisting a Comparative Advertising Lawsuit, http://www.adlawbyrequest.com/industry/CompAd.shtml 